\title{
KATEKESE KELUARGA DI ERA DIGITAL
}

Oleh: Dr. Manfred Habur Agustinus

\section{Abstraksi:}

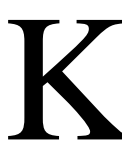

atekese sebagai bagian dari pendidikan iman berkembang sesuai dengan konteks zaman. Keluarga sebagai salah satu konteks berkatekese masuk juga dalam pusaran perkembangan yang amat sulit

dihentikan. Katekese keluarga telah masuk di era digital. Katekese keluarga sebagai salah satu media pendidikan iman menemukan peluang dan tantangan baru era digital yang mengharuskan adaptasi tanpa kehilangan esensi iman. Keluarga menjadi salah fokus dan lokus dalam berkatekese. Katekese keluarga memiliki corak baru di era digital. Era baru ini memengaruhi cara hidup keluarga-keluarga, dan dalam arti tertentu juga memengaruhi katekese keluarga. Katekese keluarga sebagai proses pendidikan iman keluarga, mau tidak mau, harus beradaptasi dengan era baru ini. Artikel ini hendak menjawabi pertanyaan manakah corak dan cara-cara katekese keluarga di era digital?

Kata Kunci: Katekese, keluarga, era digital, katekis.

\section{Pendahuluan}

Keluarga tengah menjadi fokus pastoral gereja Nusra. Pilihan tersebut menyusul SAGKI 2015 yang bertema "Keluarga Katolik, Sukacita Injili" dan Perpas Nusra bulan Juli 2016 bertema "Pendidikan Iman dalam Keluarga sebagai wujud Kerahiman”. Katekese sebagai bagian integral pastoral Gereja tak dapat tidak mesti memberi perhatian terhadap keluarga. Baik SAGKI 2015 maupun Perpas 2016 merekomendasikan pentingnya katekese keluarga. Keluarga menjadi lokus utama bina iman, di dalamnya semua anggota dapat bertumbuh menuju kedewasaan kristiani.

Pada masa sekarang ini, sadar atau tidak sadar, kita sedang mengalami era baru yang sering disebut era digital. Era baru ini memengaruhi cara hidup keluarga-keluarga, dan dalam arti tertentu juga memengaruhi katekese keluarga. Katekese keluarga sebagai proses pendidikan iman keluarga, mau tidak mau, harus beradaptasi dengan era baru ini. Prinsip kateketis mungkin tetap sama, namun cara-cara pengkomunikasian harus disesuaikan, sehingga tetap sanggup menyapa keseharian keluarga. PKKI X di Bandung tahun 2012 dan PKKI XI di Makasar tahun 2016 mendorong perlunya pengembangan bentuk-bentuk khusus katekese keluarga di era digital.

Bagaimanakah corak katekese keluarga di era digital ini? Manakah cara-cara baru yang searah dengan era digital? Tulisan ini berusaha untuk menjawab pertanyaan-pertanyaan pokok tadi. Tentu tetap bermula dari pemahaman dasar tentang katekese dan keluarga sebagai lokus istimewa karya katekese gerejawi.

\section{Katekese sebagai pendidikan iman}

Kata katekese berasal dari kata Yunani katechein yang berarti gema sabda (Istituto di Catechetica Universita' Salesiana, 1987: 104). Sabda harus digemakan untuk menumbuhkan iman. Berdasarkan asal-usul kata ini, katekese sering dipahami sebagai pewartaan sabda untuk pendidikan iman. Dengan demikian katekese sering dikaitkan dengan pengajaran, pendalaman, dan pendidikan iman. Melalui katekese umat dididik untuk semakin memahami, menghayati, dan mewujudkan imannya dalam kehidupan sehari-hari dan dengan demikian mereka menjadi semakin dewasa dalam iman. 
Dokumen-dokumen kateketik setelah Konsili Vatikan II merumuskan hakekat katekese secara bervariasi. Direktorium Kateketik Umum (1971) menekankan katekese sebagai karya gerejani, yang menuntun kelompok maupun perorangan kepada iman yang dewasa (DKU. 21). Anjuran Evangelii Nuntiandi memandang katekese sebagai bagian dari evangelisasi untuk pewartaan Sabda Kehidupan dan untuk menjadikan orangorang manusia baru (EN 22). Anjuran apostolik Catechesi Tradendae mendefinisikan katekese sebagai pembinaan anak-anak, kaum muda dan orang-orang dewasa dalam iman, yang khususnya mencakup penyampaian ajaran Kristen, yang pada umumnya diberikan secara organis dan sistematis, dengan maksud menghantar para pendengar memasuki kepenuhan hidup Kristen (CT. 18). Terakhir Petunjuk Umum Katekese (1997) melihat katekese sebagai upaya untuk memajukan dan mematangkan pertobatan awal yang dihasilkan annuncio, mendidik orang bertobat dalam iman dan menggabungkannya dalam komunitas Kristiani (bdk. PUK. 61).

Berbagai dokumen kateketis di atas, kendati merumuskan identitas katekese secara bervarisasi, pada dasarnya mengakui peran edukatif katekese. Katekese adalah proses pendidikan iman yang bertujuan untuk mendewasakan iman, memperoleh kepenuhan hidup, menjadi manusia baru dan menjadi pribadi yang bertanggung jawab dalam komunitas Gereja. Sebagai pendidikan iman, katekese mengandaikan pewartaan sabda, komunikasi dialogis, atmosfer yang bersahabat, dan penggunaan berbagai media komunikasi yang mumpuni. Dalam hal ini, katekese tidak sekedar menjadi proses penerusan ajaran kristen, melainkan satu komunikasi kehidupan yang berpusat pada Kristus.

Atas dasar itu, refleksi kateketis masa kini, lebih memahami katekese sebagai satu bentuk komunikasi Sabda Allah yang bertujuan untuk memperdalam dan mematangkan iman individu dan komunitas Kristen (Soravito, 1998:16). Komunikasi Sabda Allah tersebut merupakan satu bentuk komunikasi religius. Sasarannya terutama untuk menyentuh pertanyaan-pertanyaan dasariah manusia dan memberi jawaban atasnya. "Tidak ada komunikasi religius atau katekese jika hanya terjadi pengalihan informasi sepihak tentang ajaran, norma, dan ritus Kristen. Katekese terjadi ketika pengalaman dasariah manusia disapa, didalami, diinterpretasi dan ditransformasikan dalam proses identifikasi yang berkesinambungan dengan pengalaman Kristus dan GerejaNya" (Alberich, 2001:108).

Secara umum dalam refleksi kateketis masa kini, katekese dipahami sebagai berikut (Soravito, 1998:1721). Pertama, katekese adalah komunikasi peristiwa penjelmaan cinta Allah di dalam Kritus. "Di dalam jantung katekese kita berjumpa dengan seorang pribadi yakni Yesus dari Nazaret” (CT. 5). Di dalam Yesus dinyatakan rencana abadi keselamatan dan pembebasan manusia. Di dalam Dia manusia menemukan kunci untuk menafsir hidup dan sejarah serta jaminan dari perwujudan kemanusiaannya yang baru. Karena itu katekese harus menjadi komunikasi iman yang membantu orang tidak saja untuk mengenal Kristus melainkan untuk bersatu secara intim denganNya (bdk CT. 5). Kedua, katekese merupakan media perjumpaan dengan Allah yang terjadi melalui refleksi yang mendalam atas pengalaman manusiawi, personal dan sosial. Pengalaman manusiawi sesungguhnya merupakan locus teologicus dari perwujudan diri Allah (revelasi). Melalui pengalaman seharihari, manusia dipanggil untuk menyingkap kehadiran dan tindakan Allah dan serentak diundang untuk menjawab panggilan Allah itu dengan iman. Di sini katekese berperan untuk menginterpretasikan pengalaman personal, sosial dan eklesial dalam terang Sabda Allah yang mengarah kepada penerimaan rencana Allah dan mewujudkannya secara konkrit dalam pembaruan dunia yang lebih baik (Soravito, 1998:18). Ketiga, katekese adalah kegiatan gerejawi dan pendidikan untuk terlibat dalam kehidupan gereja dan perayaan sakramensakramennya. Kehadiran Kristus yang bangkit sekarang ini nyata kelihatan dalam komunitas kristiani atau Gereja sebagai tubuhNya yang konkrit. Komunitas kristiani merupakan tempat di mana karya keselamatan menyejarah dan dialami manusia. Dalam perspektif ini katekese tidak sekedar mengalihkan ajaran Gereja yang 
dipeliharanya dalam tradisi, tapi lebih dari itu menjadi kegiatan komunitas umat beriman untuk menafsirkan ajaran tradisi dan pesan-pesan Kitab Suci dalam konteks keseharian. Selain itu katekese merupakan pendidikan untuk berkomunitas, untuk ikut terlibat dalam karya Gereja karena iman kristen sesungguhnya bersifat eklesial. Penerimaan akan Sabda Allah membentuk satu komunitas: "Satu iman, satu baptisan, satu Allah, Bapa dari semua orang..." (Ef. 4, 5-6). Keempat, katekese adalah pendidikan untuk menjadi pelayan dan saksi iman di tengah dunia. Setiap orang kristen dipanggil untuk menghidupkan identitas baptisannya dalam sejarah: menjadi garam dan terang dunia. Di sini katekese mendidik orang beriman untuk terlibat dalam kegiatan misioner dan pembangunan dunia. Orang kristen perlu didorong untuk terlibat dan menjadi saksi dalam keluarga, profesi, dan dunia sosial politik.

\section{Katekese keluarga sebagai pendidikan iman keluarga}

Katekese sebagaimana diuraikan di atas dapat berlangsung di berbagai tempat. Katekese bisa terjadi di paroki, sekolah, komunitas basis gerejani, keluarga, dan media massa.

Keluarga merupakan tempat istimewah bagi katekese. Keluarga pada dasarnya adalah "Gereja rumah tangga" (LG. 11; FC 21; PPK 17). Sebagai Gereja rumah tangga, keluarga dapat memantulkan pelbagai aspek dan fungsi kehidupan Gereja seperti: tugas diakonia, koinonia, liturgya, kerygma, dan martiria. Tak dapat tidak, keluarga merupakan lokus utama katekese karena perannya yang unik. Keluarga dapat mengkomunikasikan Sabda Kehidupan dan membuatnya berakar dalam konteks nilai-nilai manusiawi yang mendalam. Keluarga dapat menjadi medan untuk: munculnya pengertian tentang Allah; langkah-langkah perdana doa; pendidikan moral hati nurani; pembinaan pandangan kristen tentang cinta dan pelayanan manusiawi yang dimengerti sebagai pantulan cinta Allah (PUK 226-227).

Petunjuk Umum Katekese (1997) melihat keluarga sebagai "sekolah kehidupan kristiani” (PUK 227). Di dalam keluarga orang tua menjadi pendidik dan katekis utama. Mereka mendidik anaknya melalui kesaksian hidup dan nasihat-nasihat. Melalui kesaksian hidup dari orang tua, "anak-anak akan menerima dan dengan gembira menghayati kedekatan dengan Allah dan Yesus ... sehingga pengalaman Kristiani yang pertama ini sering meninggalkan jejak-jejak yang menentukan yang berlangsung selama hidup" (PUK 226).

Melihat perannya yang begitu unik, Gereja secara niscaya perlu mengembangkan katekese keluarga. Apa yang dimaksud dengan katekese keluarga?

Katekese keluarga pertama-tama berarti katekese yang mendapat persemaian dari dalam keluarga sendiri (Istituto di Catechetica, 2002: 304-305). Hal itu berarti bahwa keluarga sebagai Gereja rumah tangga, mempunyai kewajiban untuk mengusahakan agar seluruh keluarga, orang tua dan anak-anak, memiliki iman yang dalam, yang terwujud di dalam penghayatan hidup sebagai garam dan ragi di tengah keluarga maupun masyarakat luas. Katekese keluarga ini merupakan komunikasi kehidupan iman yang timbal balik antara semua anggota keluarga. Petunjuk Umum Katekese menegaskan: "Ketika anak-anak bertumbuh, pertukaran iman menjadi timbal balik dan dalam suatu dialog kateketik semacam ini, setiap individu menerima dan memberi” (PUK 227). Orang tua tidak hanya memberi tapi juga menerima kesaksian hidup beriman dari anak-anaknya. Sebaliknya anak-anak juga tidak hanya menerima tetapi juga memberi kesaksian hidup beriman kepada orang tua mereka. Proses pendidikan iman dalam keluarga tidak pernah hanya bersifat satu arah melainkan dua arah, bahkan multi arah: orang tua ke anak, anak ke anak, anak ke orang tua, keluarga inti ke keluarga besar, dan keluarga besar ke keluarga inti.

Katekese keluarga, selanjutnya, juga berarti katekese yang diarahkan kepada keluarga-keluarga (Istituto di Catechetica, 2002: 299-304). Di sini katekese keluarga berarti suatu bentuk katekese gerejawi yang merupakan bentuk kerja sama antara sejumlah keluarga yang hendak bertumbuh dalam iman dan menghadapi 
tugas yang sama yaitu mendidik iman anak-anak. Melalui katekese keluarga Gereja berusaha menolong keluarga untuk menyadari perannya sebagai pendidik utama dalam iman dan membantu mereka untuk tetap bertumbuh dalam iman di tengah berbagai tantangan budaya global masa kini. Katekese keluarga seperti ini dapat dilakukan melalui kursus perkawinan, familly gathering, katekese umat, katekese bagi orang tua dalam kesempatan penerimaan sakramen inisiasi anak-anak mereka, dll.

Katekese keluarga yang baik pada dasarnya akan menimbulkan hal-hal positif berikut ini dalam keluarga: Anak-anak "suka pergi ke Gereja", mereka bangga dengan agamanya, dan suka menambah pengetahuan tentang imannya; orangtua dan anak-anak semakin menghayati imannya dan ada peningkatan dalam pemahaman akan isi ajaran imannya; liturgi menjadi lebih hidup, lebih merupakan kesempatan merayakan iman yang dihayati dalam hidup keseharian mereka. Liturgi diterima sebagai peristiwa naratif, mereka mendengar kisah kasih Allah kepada manusia, dan sekaligus menceritakan kepada Allah kisah hidup manusia yang rindu akan liputan kasih Tuhan; rasa persatuan atas dasar iman semakin mendalam antara anggota keluarga dan antara keluarga-keluarga serta antara keluarga dan gembala mereka; seluruh paroki yang merupakan kesatuan keluarga-keluarga menjadi komunitas iman yang hidup; keluarga-keluarga menjadi ragi dan garam dalam percaturan hidup kemasyarakatan.

\section{Keluarga di era digital}

Sebagai satu lokus utama katekese, keluarga dewasa ini sedang menghadapi tantangan era digital. Era digital tidak hanya berkaitan dengan alat-alat digital, tetapi juga berhubungan dengan budaya baru yang sedang melingkupi cara hidup manusia masa kini. Charlie Gere $(2008,10)$ melihat era digital sebagai budaya baru yang ditandai oleh perubahan cara pikir dan tingkah laku manusia sebagai akibat langsung kemajuan pesat di bidang teknologi digital. PKKI X di Bandung tahun 2012 merumuskan era digital sebagai situasi baru yang ditandai oleh maraknya penggunaan berbagai sarana teknologi digital sehingga jarak dan tempat semakin kecil, dan hal itu mengubah karakteristik budaya, perilaku dan cara berkomunikasi manusia (Komkat KWI, 2016:177).

Ada paling kurang tiga karakteristik yang mencirikan budaya baru ini (Komkat KWI, 2015:24-35). Pertama, digitalisasi dan konvergensi. Terjadi proses digitalisasi semua isi media. Isi pesan diubah ke dalam bentuk angka-angka sehingga mudah disimpan dan disebarkan ke pelbagai jaringan. Selain itu terjadi proses konvergensi yaitu penyatuan alat-alat audio, visual, cetak, dalam satu sarana digital. Pada masa ini alat-alat seperti radio, televisi, video, MP3, kamera, media cetak bisa disatukan dalam tablet, smarthone, atau laptop. Dengan hentakan atau usapan jari-jari pada alat-alat tersebut, orang bisa merambah seluruh dunia. Digitalisasi ini mengubah perilaku orang dalam mengemas dan mengelola informasi. Pesan dapat didistribusikan secara multiplexing, artinya diteruskan dalam beragam jenis dan dalam jumlah yang berlimpah ruah ke segala penjuru jagad. Kedua, interaktif dan saling terkait. Komunikasi pada masa sekarang menjadi lebih dialogis interaktif. Komunikasi media cetak, audio-visual tidak lagi bersifat statis satu arah melainkan multi arah. Orang bisa berkomunikasi dari berbagai tempat, berbagai arah, dan dapat berpindah-pindah sejauh ada signal dan sarana digital yang konvergen. Orang bisa berkomunikasi dengan siapa pun yang dia mau dari tempat di mana pun ia berada. Muncul gejala alone together yakni orang yang tampak menyendiri dengan gadgetnya namun berinteraksi dengan semua orang di seluruh dunia. Tampak pula gejala together alone: orang bisa berkumpul bersama namun masing-masing sibuk dengan gadgetnya. Ketiga, virtual dan mendunia. Kemajuan internet pada era digital memungkinkan terjadinya komunikasi antarpribadi secara virtual yakni melalui layar komputer, smartphone, gadget. Komunikasi tersebut bersifat maya atau virtual karena masih bersifat permukaan kendati merepresentasi kenyataan yang sebenarnya. Perkembangan internet juga memungkinkan terjadinya komunikasi global-mondial. Orang dapat berkomunikasi dengan orang lain di mana pun di dunia ini secara langsung. 
Komunikasi tersebut tidak memandang usia dan status. Siapa saja dapat berinteraksi secara egaliter. Tukang ojek, ibu rumah tangga bisa berkomukasi dengan paus, presiden, politisi, artis, dll. Mereka bisa berselfie dan mengirim hasil jepretannya ke seluruh dunia tanpa merasa takut dengan status sosialnya. Mereka menjadi warga dunia dan dunia berada dalam satu genggaman.

Era digital dengan berbagai karakteristik di atas memengaruhi keluarga-keluarga. Kini banyak keluarga yang tidak hanya membutuhkan smarthone, tablet, atau laptop, tapi juga sambungan internet. Di kota-kota besar, banyak orang seakan tak bisa hidup tanpa internet. No internet, no life. Cepat atau lambat keluargakeluarga di Flores akan terpengaruh oleh kemajuan ini. Karena itu budaya digital akan menjadi bagian kehidupan keluarga. Keluarga bisa terbuka ke dunia, dan dunia dengan seluruh kompleksitas budayanya masuk ke dalam keluarga dan memengaruhi sikap, mental, dan gaya hidup keluarga.

Lahir generasi baru dalam keluarga yang sering disebut generasi Z. Generasi Z adalah generasi digital yang mahir dengan teknologi informasi seperti facebook, twitter, instagram, SMS, WA, Line, dan berbagai aplikasi komputer (Akhmad Sudrajat, 2012). Beberapa sifat menonjol dari generasi Z antara lain: bebas mengkomunikasikan pikiran dan perasaannya secara spontan, tanpa rasa takut dengan siapa pun dan level apa pun melalui jaringan internet; cenderung toleran dengan perbedaan budaya dan sangat peduli dengan lingkungan; multi-tasking yakni dapat melakukan berbagai aktivitas dalam satu waktu yang bersamaan dan karena itu mereka ingin serba cepat dan langsung, instan, tidak sabar, dan kurang menghargai proses; cenderung kurang memberi tempat kepada komunikasi verbal, bersikap egosentris dan individualis.

Era digital dengan kemajuan teknologi digital membawa pengaruh positif tetapi juga negatif bagi keluarga masa kini. Pengaruh-pengaruh positif antara lain ada kemudahan dalam mengakses informasi dan berbagai macam hiburan keluarga, bisa mendekatkan anggota keluarga dan sahabat yang jauh, bisa menciptakan relasi pergaulan lewat dunia maya, dan dapat mengembangkan berbagai kemampuan dan keterampilan dengan sarana belajar on line. Sementara pengaruh-pengaruh negatif juga bisa menimpa keluarga-keluarga. "Banyak pesan dalam media yang melemahkan nilai-nilai hidup keluarga, mempropagandakan nilai-nilai dan modelmodel tingkah laku yang merendahkan, dengan menyajikan pornografi dan kekerasan secara vulgar, dengan menanamkan relativisme di bidang moral dan sikap skeptis terhadap agama, dengan menyebarluaskan laporan yang mengubah atau memanipulasi peristiwa dan persoalan-persoalan yang beredar, dengan memuat iklan-iklan berani yang menarik naluri rendah, dan dengan mengagungkan pandangan hidup palsu yang menghalangi diwujudkanya saling penghormatan, keadilan, dan damai" (Komkat KWI, 2015: 44-45). Selain itu relasi personal dalam keluarga cenderung terganggu karena masing-masing orang akan sibuk dengan alat-alat digitalnya. Timbul gejala together alone, keluarga ada bersama namun sibuk dengan dunia mayanya sendiri. Bukan tak mungkin orang bisa menjadi budak media digital.

Berhadapan dengan berbagai kemungkinan pengaruh budaya baru era digital di atas, ada tiga kemungkinan sikap yang bisa muncul dalam keluarga-keluarga. Pertama, sikap permisif yakni sikap yang membiarkan semua anggota keluarga untuk menggunakan media digital seturut kemauannya tanpa perlu ada kontrol bersama. Kedua, sikap agresif yakni sikap yang tegas melarang dan menolak penggunaan media digital dalam keluarga. Ketiga, sikap asertif yakni sikap tegas untuk menggunakan media digital secara tepat dan bertanggung jawab (Adhi, 2016: 20).

Sikap yang perlu dikembangkan dalam keluarga pada era digital ini adalah sikap asertif. Keluarga dengan sikap asertif lebih fokus kepada peluang dan pemanfaatannya dari pada kekuatirannya; lebih berusaha memberikan dorongan, merangkul dan mendukung keterlibatan bermedia digital; membantu menyeimbangkan waktu penggunaan media digital secara bijak dan cerdas; menyediakan alternatif bijak agar tidak menjadi budak media digital; senantiasa mendampingi untuk membuat orang semakin sadar bermedia digital tanpa prasangka 
buruk. Keluarga yang sadar media akan tahu bahwa teknologi digital dapat memengaruhi cara pikir dan perilaku; mereka tahu kapan harus menggunakan media digital dan kapan harus menghentikannya guna menciptakan saat-saat hening dan saat-saat kebersamaan; tahu membedakan mana penggunaan media digital secara fungsional dan mana sikap ketergantungan yang memperbudak, mereka fokus untuk memanfaatkan media digital untuk menghubungkan sesama anggota keluarga (Adhi, 2016:21-22).

Dengan sikap asertif jelas era digital menjadi peluang untuk berbagai aktivitas pendidikan termasuk pendidikan iman dalam keluarga. Era digital memberi kemungkinan-kemungkinan baru berkatekese dalam keluarga.

\section{Katekese keluarga di era digital}

Era digital membuka peluang baru bagi katekese keluarga. Kehadiran media digital pada era ini, bila dimanfaatkan secara bertanggung jawab, merupakan anugerah Allah yang tak ternilai. Sebagai anugerah Allah ada dua perspektif Gereja terhadap era digital dengan kemajuan internetnya. Pertama, perspektif instrumentalisasi, yaitu satu cara pandang yang menganggap internet sebagai instrumen yang andal untuk pewartaan Sabda Allah demi pendidikan iman. Gereja harus menggunakan gelanggang internet untuk mewartakan Sabda. Paus Benediktus XVI pada hari komunikasi Sedunia ke-44 tahun 2010 menandaskan: "Dunia komunikasi digital, dengan kemampuannya untuk berekspresi nyaris tanpa batas, membuat kita lebih menghargai seruan Paulus: 'Celakalah aku bila aku tidak mewartakan Injil (1 Kor 9,16)". Adalah tidak tepat menolak kehadiran teknologi digital ini lantaran kemungkinan dampak negatif yang menyertainya. Sebaliknya, dengan peluang yang mengiringinya, teknologi digital ini, harus dimanfaatkan untuk tugas pewartaan. Keengganan untuk tidak memanfaatkannya adalah satu kecelakaan. Kedua, perspektif perjumpaan, yaitu satu cara pandang yang menganggap era digital sebagai "aeropagus baru" tempat berlangsungnya perjumpaan baru antara manusia dan kebudayaan. Perjumpaan secara maya dalam dunia digital ini disertai munculnya budaya baru yang terungkap dalam cara-cara baru berkomunikasi, bahasa-bahasa baru, dan psikologi yang baru. Berdasarkan kenyataan ini, maka media digital, terutama jaringan internet, tidak sekedar menjadi sarana pewartaan akan tetapi juga menjadi gelanggang baru inkulturasi injil dengan budaya baru yang tercipta dari kemajuan teknologi digital tersebut (Putranto, 2016:84-85).

Berdasarkan pandangan yang positif tentang era digital di atas maka katekese kelurga di era digital tak dapat tidak harus memanfaatkan media digital secara baik dan mau terlibat dengan ungkapan-ungkapan baru kehidupan iman dalam era digital. Katekese keluarga sebagai persemaian Sabda Allah dari dalam keluarga sendiri menuntut agar keluarga memiliki kesadaran bermedia dan pada gilirannya dapat menjalankan katekese berbasis media di dalam keluarga. Di sini orang tua sebagai katekis utama dalam keluarga mesti memiliki sikap asertif terhadap media dan bertanggung jawab untuk membimbing anak-anaknya agar bisa menggunakan media digital secara tepat dan secara bersama-sama dapat mengkomunikasikan imannya menurut bahasa dan psikologi era digital. Maka ada dua bentuk katekese keluarga dalam hal ini yakni katekese tentang kesadaran bermedia dan katekese berbasis penggunaan alat-alat media digital.

\section{Katekese kesadaran bermedia dalam keluarga}

Media digital pada dirinya sendiri sebetulnya bersifat netral namun perilaku manusia yang menggunakan media tersebut bisa mendatangkan hal-hal negatif atau positif. Karena itu kesadaran bermedia digital sangat diperlukan dalam keluarga. Katekese tentang kesadaran bermedia ini merupakan hak dan kewajiban orang tua. Tentu mereka pertama-tama harus memiliki kesadaran bermedia. Mereka harus menjadi contoh penggunaan media digital secara tepat. Selanjutnya mereka bertanggung jawab untuk mendampingi anak-anaknya dalam 
penggunaan media. Sikap asertif sangat dibutuhkan di sini. Mereka dapat mengkomunikasi sikap Gereja mengenai media digital, yang meyakini bahwa media tersebut adalah anugerah Allah yang harus digunakan untuk pemanusiaan manusia dan menjadi medan perjumpaan baru dengan wahyu Allah (PKKI X). Dalam kerangka itu maka anak-anak perlu menggunakan media digital ini secara bijak demi perkembangan kepribadian mereka.

Pendampingan untuk kesadaran bermedia tak harus mengandaikan bahwa orang tua lebih tahu mengoperasikan alat-alat digital. Mungkin anak-anak lebih cepat belajar dan menguasai penggunaan media tersebut. Namun tidak berarti orang tua lepas tangan. "Orang tua perlu memberikan penyadaran terus-menerus kepada anak-anak mengenai keberadaan media digital yang bisa mengembangkan, tetapi bisa juga merusak; yang bisa untuk kepentingan positif, tetapi juga bisa berakibat negatif' (Komkat KWI, 2015: 64). Di sini orang tua kadang perlu mengatur kapan boleh menggunakan media digital, dan kapan tidak. Di samping itu orang tua perlu mendukung pengembangan bakat-bakat tertentu dari anak-anak yang kadang muncul setelah mereka berkenalan dengan dunia internet. Banyak sekali keterampilan yang bisa berkembang melalui pembelajaran on line di internet.

Katekese kesadaran bermedia tak harus langsung berkaitan dengan dunia digital. Kesadaran bermedia pada dasarnya juga bertautan dengan pembinaan suara hati. Suara hati adalah self censorship, yakni penyaring personal yang paling ampuh untuk menangkal berbagai pengaruh buruk media digital (PKKI XI). Pembinaan suara hati berkaitan cinta dan persahabatan, serta berhubungan dengan pembinaan nilai-nilai etis dan religius dalam keluarga. Pembinaan nilai-nilai dimaksud dilakukan melalui pembiasaan. Maka seluruh anggota keluarga perlu memiliki kebiasaan makan bersama, berdoa bersama, bersenda gurau bersama, pembagian tugas dan tanggung jawab tertentu, dll. Penting juga untuk membiasakan adanya saat-saat hening dalam keluarga. Dalam hening setiap anggota keluarga dapat saling mendengarkan dan dapat memahami diri sendiri serta mampu memberikan gagasan-gagasan yang syarat makna. Dalam hening pula orang dapat membuka hatinya bagi Allah yang senantiasa ingin menyapa manusia.

\section{Katekese berbasis penggunaan media digital dalam keluarga}

Katekese sebagai persemaian Sabda Allah dalam keluarga tentu tidak hanya berhenti pada kesadaran bermedia. Keluarga juga dapat menggunakan media dan menyesuaikan diri dengan cara-cara baru berkomunikasi iman dalam era digital. Ada tiga aktivitas bermedia yang bisa dilakukan oleh anggota keluarga dalam kerangka katekese berbasis media digital yakni: browshing, chatting-mailing List-Social media, dan blogging.

Browshing adalah penjelajahan informasi-informasi di internet dengan menggunakan kolom-kolom pencari seperti "Google", "Yahoo", dan "Ask" (Muktar dan Iskandar, 2012:327; Komkat KWI, 2015:68). Keluarga dapat melakukan penjelajahan informasi tentang iman katolik di internet. Bila ada pertanyaan tentang iman dari salah seorang anggota keluarga maka keluarga secara bersama-sama atau secara personal melakukan browshing melalui mesin pencari untuk menemukan jawabannya. Mesin pencari seperti "Google" dan "Yahoo" misalnya, selalu terhubung dengan jutaan web atau blog tentang iman Katolik. Pesan-pesan pewartaan yang termuat dalam Web-web tersebut lasimnya sudah dikemas seturut bahasa dan idiom baru dunia digital. Pesan dirumuskan secara singkat, menarik, penuh resonansi emosional yang menggetarkan. Pesan-pesan tersebut dapat menjadi bahan diskusi dan permenungan lebih lanjut dan bila mungkin bisa dishare ke anggota yang tidak hadir melalui email, WA, FB, Twitter, dll. Kalau ada anggota keluarga yang hendak mengadakan studi mendalam tentang topik iman tertentu, kegiatan browshing ini juga sangat membantu. Sekarang ini 
Kompendium Katekismus Gereja Katolik dan perpustakaan teologi sudah tersedia secara melimpah dalam situssitus web, dalam aneka bahasa.

Chatting, mailing list dan social media merupakan aktivitas yang lebih interaktif dalam komunikasi berbasis media digital. Anggota keluarga yang tinggal berjauhan karena alasan studi atau tugas dapat mengobrol santai melalui media sosial seperti FB, Line, WA, Skype, dll. Mereka bisa membentuk grup keluarga dan keluarga besar dalam FB, WA, dan mailing list misalnya. Dengan sesama anggota grup mereka bisa saling berbagi cerita, mengirimkan ayat-ayat emas kitab suci, dan menshare renungan-renungan singkat, film-film rohani yang pendek, dan juga slide-slide rohani yang menggugah pertobatan (Komkat KWI, 2015:69-70). Anggota keluarga yang ada bersama di rumah, bila memungkinkan dapat mengobrol langsung untuk mendalami dan memberi input tentang "status" yang ingin dishare melalui media sosial. Akan lebih menarik kalau ngobrol tersebut menggunakan skype atau Line yang memungkinkan dialog verbal dan saling melihat langsung di layar.

Blogging "merupakan aktivitas dalam dunia internet yang lebih kompleks karena di dalamnya ada aktivitas menyusun, mengelola, dan menuliskan suatu informasi atau isi pada media internet yang sering disebut weblog". Untuk membuat weblog dibutuhkan biaya yang tidak sedikit, membutuhkan ketrampilan khusus bermedia, kemampuan menulis dan merangkai pesan secara menarik, dan terutama komitmen waktu yang cukup. Tentu aktivitas ini tidak dianjurkan untuk semua keluarga, namun yang memiliki komitmen khusus untuk ini, peluangnya sangat terbuka. Blogging sangat cocok untuk berbagi pengetahuan dan pengalaman iman. Pengalaman iman ini bisa meneguhkan keluarga-keluarga di seluruh dunia. Di Indonesia katolisitas.org, sesawi.net adalah contoh-contoh webside yang berkembang dari weblog yang dikelola keluarga-keluarga.

\section{Peran katekis akademis bagi katekese keluarga di era digital}

Sebagaimana dijelaskan sebelumnya, katekese keluarga tidak hanya menyangkut persemaian iman dari dalam keluarga sendiri, tetapi juga merupakan usaha pihak Gereja untuk mendampingi keluarga-keluarga agar bertumbuh dalam iman. Dalam hal ini, para imam dan katekis, terutama katekis akademis, dipanggil dan diutus untuk menjadi pendidik iman bagi keluarga-keluarga. Mereka bertanggung jawab untuk menyelenggarakan katekese keluarga yang melibatkan keluarga-keluarga dalam berbagai momen penting perjalanan hidup keluarga.

Di era digital sekarang ini, katekis akademis dapat mengembangkan katekese keluarga berbasis media. Untuk itu para katekis akademis dituntut untuk melek media. Mereka harus memiliki sikap dan pandangan yang positif terhadap media digital dan menjadi tokoh panutan dalam memanfaatkannya bagi karya pewartaan. PKKI $\mathrm{X}$ di Bandung tahun 2012 mendorong katekis untuk merambah dunia digital dan mewarnainya sebagai arena baru berkatekese, termasuk berkatekese keluarga. Katekis diharapkan untuk menguasai media, bahasa dan cara berkomunikasi di era digital. Mereka tidak saja menjadi pengguna sarana digital, khususnya internet, namun juga memberi kontribusi dan inspirasi visioner (Komkat KWI, 2015: 184).

Dalam rangka katekese keluarga berbasis media ini, tentu keluarga-keluarga perlu dibantu untuk memiliki kesadaran bermedia. Karena itu, para katekis berkewajiban untuk menyelenggarakan katekese kesadaran bermedia, misalnya dengan bersama-sama mendalami tema-tema hari komunikasi sosial sedunia. Setiap tahun, pada hari komunikasi sosial sedunia, Bapa Suci mengeluarkan pesan khusus yang biasanya memberi makna teologis kehadiran media komunikasi sosial.

Dengan bertumbuhnya kesadaran bermedia, para katekis dapat mengembangkan lebih lanjut katekese keluarga berbasis media digital. Bersama keluarga-keluarga, katekis terlibat dalam aktivitas browsing, chattingmailing list-social media, dan blogging untuk pendidikan iman. Ada banyak peranan yang bisa dimainkan oleh 
katekis dalam aktivitas kateketis ini. PKKI X di Bandung mengutarakan beberapa peran berikut (Komkat KWI, 2015: 75-78): Pertama, sebagai fasilitator. Seorang katekis dapat menjadi seorang pelancar yang mengatur komunikasi iman keluarga-keluarga dalam dunia maya. Katekis dapat membentuk grup khusus keluargakeluarga misalnya grup BBM, grup WA, grup mailing list, dll. Melalui grup-grup tersebut mereka didorong untuk terlibat dalam obrolan tentang iman kristen, membagi pengalaman iman dan pengetahuan iman. Katekis juga dapat membantu anggota grup untuk menginterpretasi pengalaman-pengalaman harian dalam terang iman kristen, dengan demikian aktivitas media digital ini dapat menjadi sarana perjumpaan dengan Tuhan. Kedua, sebagai penghubung. Katekis dapat melakukan aktivitas browshing untuk mencari informasi berupa tulisan, video, dan slide rohani dalam berbagai blog dan webside di internet dan setelah mendapatkannya, dia bisa menautkannya ke grup BBM, WA, FB, mailing list, dll. Ketiga, sebagai inspirator dan penyaji. Katekis bisa secara proaktif terlibat untuk mengisi gagasan tentang iman kristen pada web-web dan blog-blog interaktif yang tersedia. Dia juga bisa membentuk blog sendiri, satu blog yang mengkhususkan perhatiannya pada masalah perkembangan iman dalam keluarga. Tentu peran ini mengandaikan keterlibatan penuh waktu dan membutuhkan keahlian khusus dalam mengelola blog, termasuk keahlian untuk mengenal bahasa-bahasa khusus dan psikologi khusus era digital. Keempat, sebagai pencerita. Katekis dapat berbagi kisah-kisah inspiratif atau pengalaman hidup pribadi yang dapat memperkuat iman keluarga-keluarga melalui media sosial. Kelima, sebagai sahabat. Katekis dapat menjadi sahabat bagi keluarga-keluarga, sahabat yang menemani, yang mau berbagi pengalaman iman melalui media sosial. Keenam, sebagai pendoa. Katekis juga bertugas mendoakan keluarga-keluarga. Melalui media sosial dia bisa mengirimkan teks-teks doa, ayat-ayat emas Kitab Suci kepada keluarga-keluarga, namun secara personal dia berkewajiban untuk mendoakan mereka.

\section{Penutup}

Dari uraian di atas, katekese keluarga di era digital mengacu pada pemanfaatan secara bijak peluangpeluang kateketis yang disediakan oleh kemajuan teknologi media digital sekarang ini. Katekese keluarga di era digital berbasis media digital. Keluarga-keluarga dapat melakukan aktivitas browshing, chatting, dan blogging untuk mendalami dan mengkomunikasikan imannya. Ada banyak resiko, namun bila dikembangkan secara bertanggung jawab katekese model ini juga dapat membantu keluarga-keluarga untuk berkembang menuju kedewasaan iman.

Katekis akademis dewasa ini mempunyai tanggung jawab untuk terlibat secara aktif dalam katekese berbasis media digital ini. Mereka harus memiliki kesadaran bermedia dan kompetensi khusus untuk berkatekese keluarga berbasis media. Kurikulum pendidikan para calon katekis, mau tidak mau, mesti segera memperhitungkan kompetensi khusus ini. Kompetensi dimaksud tentu harus didukung oleh spiritualitas yang mendalam.

\section{Daftar Rujukan:}

Adhi, Purwono Nugroho. 2016. Keluarga dan Era Digital, dalam www.slideshare.net/karangpanas/keluarga-era-digital, diunggah pada pukul 21.30, 2 Oktober 2016.

Alberich, E. 2001. La catechesi oggi. Manuale di catechetica fondamentale. Leumann (Torino): Elledici.

Gere, Charlie. 2008. Digital Culture-Expanded Second Edition, dalam http://portiaplacino.files.wordpress.com/2011/02/digital-culture.pdf., diunggah pada pukul 10.00, 26 September 2016.

Hardawiryana, R (penterj.).1993. Dokumen Konsili Vatikan II. Dokpen KWI-Obor, Jakarta. 
Istituto di Catechetica. Facolta' di Scienze dell'educazione-Universita' Pontificia Salesiana. 2002. Andate \& insegnate. Manuale di catechetica. Leumann (Torino): Elledici.

------. 1987. Dizionario di Catechetica. Leumann (Torino): Elledici

Komkat KWI. 2016. Katekese di era digital. Peran imam dan Katekis dalam Karya Katekese Gereja Katolik Indonesia di Era Digital. Kanisius, Yogyakarta.

-------. 2015. Hidup di Era Digital. Gagasan Dasar dan Modul Katekese. Kanisius, Yogyakarta.

Konferensa Waligereja Indonesia. 2011. Pedoman Pastoral Keluarga. Obor, Jakarta.

Kongregasi untuk Imam. 2000. Petunjuk Umum Katekese. Terjemahan Komkat KWI. Dokpen KWI, Jakarta.

Muktardan Iskandar. 2012. Desain Pembelajaran Berbasis TIK. Referensi, Jakarta.

Putranto, C. B. 2016. Rambahlah Benua Digital: Dorongan Pimpinan Gereja tentang Internet. Dalam Komkat KWI. Katekese di era digital. Peran imam dan Katekis dalam Karya Katekese Gereja Katolik Indonesia di Era Digital. Kanisius, Yogyakarta.

Soravito, L. 1998. La catechesi degli adulti. Orientamenti e proposte. Leumann (Torino): Elledici.

Sudradjat, Akhmad. 2012. Generasi Z dan Implikasinya terhadap Pendidikan. Dalam http://akhmadsudrajad.wordpress.com/2012/10/05/generasi-z-dan-implikasinya-terhadap-pendidikan/, diunggah pada pukul 11.00, 26 September 2016.

Yohanes Paulus II, Paus. 2006. Catechesi Tradendae. Terjemahan Hardawiryana SJ. Dokpen KWI, Jakarta. 